\title{
"Only People Who Know It Here Speak Well of It...": The Location of Social Housing in Brazilian Cities and Effects of Territorial Stigmatization ${ }^{1}$
}

\author{
Mario Peters, Luciana Teixeira de Andrade ${ }^{2}$
}

DOI - 10.25160/v5i2.ga.2

\section{Introduction}

Brazilian cities are famous for their enormous housing deficit. The construction of large housing estates, called conjuntos habitacionais, has been a common approach to solve this problem that primarily affects the poorest parts of society. Most conjuntos, however, are located far away from the city centers where they are deprived of urban infrastructures and social services. Throughout many years, people who had been removed from centrallylocated slum settlements (favelas) were resettled at these housing estates. This has led to the fact that in Brazil conjuntos habitacionais are generally seen as places of the poor. As a consequence, the residents are often confronted with stereotype views that outsiders hold on them and their place of residence.

This article takes the Conjunto IAPI in Belo Horizonte, a housing estate constructed in the 1940s, as a case study to discuss how stigmatization influences the daily lives of social housing dwellers. Contrary to most public housing estates in Brazilian cities, the Conjunto IAPI is located within the city. It is our aim to show that the IAPI's location has had ambivalent effects: the proximity to Belo Horizonte's central area brought important advantages for the residents; above all it provided them with access to urban infrastructure and services offered by public and private institutions. At the same time, the housing estate

\footnotetext{
${ }^{1}$ A shorter version of this article was presented as a paper at the European Network for Housing Research Conference held in Lisbon in June 2015. The article is based on the research carried out by Mario Peters for his doctoral thesis, entitled Social Housing, Socio-Spatial Segregation and Territorial Stigmatization in Brazil: The Conjunto IAPI, Belo Horizonte c. 1940-1973. The thesis was defended at the Department of History at Leibniz Universität Hannover, Germany, in June 2016. Furthermore, the article is based on Luciana Teixeira de Andrade's research on urban segregation and stigma.

${ }^{2}$ Mario Peters has a PhD in History at the Faculty of Humanities at Leibniz Universität Hannover, Germany. He is teaching assistant at the History Department at Leibniz Universität Hannover and researcher at the interdisciplinary Centre for Atlantic and Global Studies, at the same university. Luciana Teixeira de Andrade has a Phd in Sociology from Instituto Universitário de Pesquisas do Rio de Janeiro (IUPERJ). She is Associate Professor at the Departamento de Ciências Sociais at Pontifícia Universidade Católica de Minas Gerasis (PUC Minas), Brazil, and at the Programa de Pós-Graduação em Ciências Sociais at PUC Minas.
} 
is situated within the Lagoinha region, a traditionally disreputable area ${ }^{3}$, and close to the Pedreira Prado Lopes, one of Belo Horizonte's oldest and largest favelas. We argue that the proximity to the favela and the stigma that housing estates have acquired as places of the poor work together in 'contaminating' the IAPI' s reputation.

The article provides an overview of the early history of social housing in Brazilian cities. In order to show how and why the residents benefitted from the central location of the Conjunto IAPI in Belo Horizonte, we will consider the local urban development of the housing estate's neighborhood since the 1940s. The third section discusses some crucial aspects concerning the different development of central areas and urban peripheries in Brazilian cities in the latter half of the $20^{\text {th }}$ century. This is important to achieve an understanding of the origins and durability of territorial stigmatization. In the last part, we will make use of interviews with long-term residents of the IAPI about their experiences of living in the housing estate in the past and in the present. By analyzing these oral sources we aim at conclusions on the far-reaching negative effects that territorial stigmatization has had on the lives of the residents. In this context, the article also discusses several strategies that the interviewees adopt as responses to the experience of being confronted with stereotypes. By considering recent developments at the Conjunto IAPI in Belo Horizonte, we intend to show that stigmatization does not affect all forms of popular housing in the same ways and that public housing estates, contrary to favelas, can effectively work towards a change of their image.

\section{On Methods and Sources}

While countless works on favelas and other types of precarious settlements in Brazilian cities have been written by authors from various academic fields since the $1960 \mathrm{~s}^{4}$, far less research has been published on Social Housing programs and the conjuntos habitacionais. The activities that the so-called Institutos de Aposentadoria e Pensão (IAP) exercised in this field between the 1930s and the 1960s have only recently come into the focus of research. ${ }^{5}$ Most works that have

\footnotetext{
${ }^{3}$ Lagoinha was first occupied by immigrants who came to build Belo Horizonte in the late nineteenth century. Later it became a bohemian neighborhood with bars and brothels, hence its ambiguous reputation as a district of laborers, families and bohemians.

${ }^{4}$ For a good overview of the historiography on favelas see VALLADARES (2005).

${ }^{5}$ BONDUKI (1998) published a pioneering study on the history of Social Housing in Brazil between 1930 and 1964 . The IAPs and the housing complexes built by these institutions have been studied by several Brazilian architects in the last years
}

PRASILIANA- Journal for Brazilian Studies. Vol. 5, n.2 (July, 2017). ISSN 224.5-4373. 
been published on this topic do not discuss important socio-historical aspects like the development of neighborhood relations or the interrelation between social housing, processes of socio-spatial segregation and stigmatization in detail. This article contributes to filling this research gap. In view of the lack of academic works on the history of social housing in Belo Horizonte, our study is based on contemporary written documents, namely the annual reports published by the municipal administration at the time of the Conjunto IAPI's construction and during the following years. Data on the effects of stigmatization on the residents' daily lives stems from interviews with ten long-term inhabitants of the Conjunto IAPI, one former inhabitant and the Church Father of the local parish Paróquia São Cristovão. ${ }^{6}$ The search for interview partners ${ }^{7}$ focused on individuals who had lived in the housing estate either for a long time or during the period between the late 1940s and the early 1970s. Experiences with local public institutions that are situated in the IAPI's immediate vicinity, respectively inside the housing complex, e.g. the Hospital Municipal Odilon Behrens, the Escola Municipal Honorina de Barros, or the local parish were a further important criterion. Concerning the time of residence in the Conjunto IAPI it is important to mention that most interviewees had moved there or were born in the public housing estate between 1947 and 1957. Eight interviewees were male, four female and most of them were between 55 and 70 years old. ${ }^{8}$ The interviews were significant sources to discover the meaning of neighborhood relationships and sociability for the residents of the Conjunto IAPI. Furthermore, the participants were asked to tell what they had perceived about the conjunto's reputation during their interaction with outsiders. As we will explain, by analyzing their statements it

\begin{abstract}
(BRUNA 2010, BONDUKI, KOURY 2014). Students of architecture and urbanism have written their master and doctoral theses on the subject of social housing (ALMEIDA 2007, BOTAS 2011, FERRARI 2013). However, these works focus on the architectural design and the planning of conjuntos habitacionais and discuss the action of the architects responsible. Historians have studied a variety of topics which are related to urban history and housing. Astonishingly, they have permanently ignored the IAPs. Among the international research community the IAPs and their significance for the history of housing in Brazil are still nearly unknown. Concerning more recent social housing programs, Capes databases mention six doctoral theses and three articles on conjuntos habitacionais. Most of these works have been written by architects who focused on specific case studies. Recently, collections evaluating the governmental Minha Casa, Minha Vida program (CARDOSO 2013, AMORE et. al. 2015) have been published. Given the program's recency, such evaluations focus on territorial aspects and the design of public housing politics.
\end{abstract}

${ }^{6}$ The twelve interviews of which seven are referred to in this article were conducted by Mario Peters between 2012 and 2014, as part of the research for his doctoral thesis. Conversations took place inside the participants' apartments, at the IAPI's public square and at the Igreja São Cristovão that is situated within the housing complex.

${ }^{7}$ The names of all interviewees have been changed.

${ }^{8}$ Two interviewees were over eighty years old. Two participants were in their seventies. One interview partner had not reached the age of 50 when the interview was conducted.

PRASIlianA- Journal for Brazilian Studies. Vol. 5, n.2 (July, 2017). ISSN 2245-4373. 
is possible to understand how the experience of belonging to a stigmatized group led the residents to highlight the IAPI's human qualities.

\section{The Historical Development of the Housing Deficit in Brazilian Cities and the Beginnings of Social Housing}

Since the late $19^{\text {th }}$ century, rural migrants, former slaves and immigrants from Europe and Asia came to Brazilian cities in search of better living conditions. They found accommodation in the so - called cortiços, casas de cômodos, estalagens or favelas, where housing conditions used to be miserable (BENCHIMOL 1992). In the early $20^{\text {th }}$ century, state authorities, the upper echelons of society and the local press saw such settlements as insalubrious places where the spread of diseases was inevitable. Furthermore, the residents suffered from prejudices and discrimination since outsiders perceived them as criminals and vagabonds. Before 1930, municipal authorities and the national government left the provision of workers' housing to the private sector. In the absence of coherent and effective state action, the clandestine construction of dwellings often was the only option for the poor (SILVA 1989). Actually, the state was far from being a passive observer of the urban growth. However, instead of developing strategies towards a solution of the worsening housing crisis, the authorities shared elitist perspectives on precarious settlements as a threat to the city and evicted them in violent and repressive manners (BONDUKI 2011).

In the 1930s, the ongoing process of urbanization and the steady growth of irregular settlements became subjects of public discourse. The increasing attention which civil society paid to the housing question put pressure on the state government under Getúlio Vargas. From the authorities' point of view, the intervention of the state was actually important for their own purposes: adequate housing conditions for workers supported the reproduction of workforce and fostered the process of industrialization and the project of national development (desenvolvimento nacional) (BONDUKI 2011: 73-77). Moreover, the organization of housing programs was expected to create public support for the government and contribute to the stabilization of order (MELO 1991).

Since 1937, the Institutos de Aposentadoria e Pensão (IAP), which the Vargas government had established as corporatist social welfare institutions for several professional sectors, acted as the most important state organs for social housing and continued to do so until their extinction by the military regime in the second half of the 1960s (BONDUKI 2011). They provided apartments for rent in vertical public housing estates and detached houses for their

PRASILIANA- Journal for Brazilian Studies. Vol. 5, n.2 (July, 2017). ISSN 2245-4373. 
associated members. The IAPs organized most of their housing programs in Rio de Janeiro, the southeastern federal states São Paulo and Minas Gerais, and later also in Brasília. ${ }^{9}$

Research has pointed to some principles that were relevant for the construction of public housing estates. First of all, it was necessary to keep the expenses low. Therefore, planners had to take economic considerations into account. Practicality and the industrialized production of construction materials were further guidelines (ALMEIDA 2007, BONDUKI 2011). The architects who worked for the IAPs were convinced that the establishment of urban infrastructures in the neighborhood of the housing estates was essential. They regarded schools, daycare and healthcare centers and commercial facilities as particularly important. Sometimes, libraries and sports fields ought to stimulate the development of sociability. On the one hand, these infrastructures ought to guarantee a higher comfort and quality of life. On the other, the installation of equipment for collective use aimed at the moral education and social control of the inhabitants (BONDUKI 2011).

It is important to notice that only those workers who were affiliated to one of the IAPs had the formal right to apply for an apartment in the conjuntos. People who worked under informal conditions, rural workers as well as the unemployed remained excluded from the social housing programs (BONDUKI 2011). Actually, the Estado Novo and the following populist governments offered public services only to those groups who were registered within the corporatist system. ${ }^{10}$ Furthermore, personal and political favors and clientelism often influenced the selection of the residents.

\section{The Conjunto IAPI in Belo Horizonte: a Housing Estate near the City Center}

In most cases, the IAPs decided to build their housing estates on the urban periphery where land was cheaper. However, the Instituto de Aposentadoria dos Industriários (IAPI), the industrial workers' pension fund, constructed some of its conjuntos close to central areas or working-class districts (FERRARI 2013). On 29 November 1940, the IAPI and Belo Horizonte's municipal administration under Juscelino Kubitschek agreed on the construction of a public housing estate in the Lagoinha district and called this project bairro popular. The

\footnotetext{
${ }^{9}$ According to Bonduki (2011: 111), this regional focus corresponded to the unequal distribution of political and economic power in Brazil.

${ }^{10}$ The Brazilian political scientist Wanderley Guilherme dos Santos (1979) developed the cidadania regulada concept to describe this practice.
}

PRASILIANA- Journal for Brazilian Studies. Vol. 5, n.2 (July, 2017). ISSN 224.5-4373. 
Prefeitura de Belo Horizonte (PBH) provided an area of 70.000 square meters, situated about 1$1 / 2$ miles north of the city center.

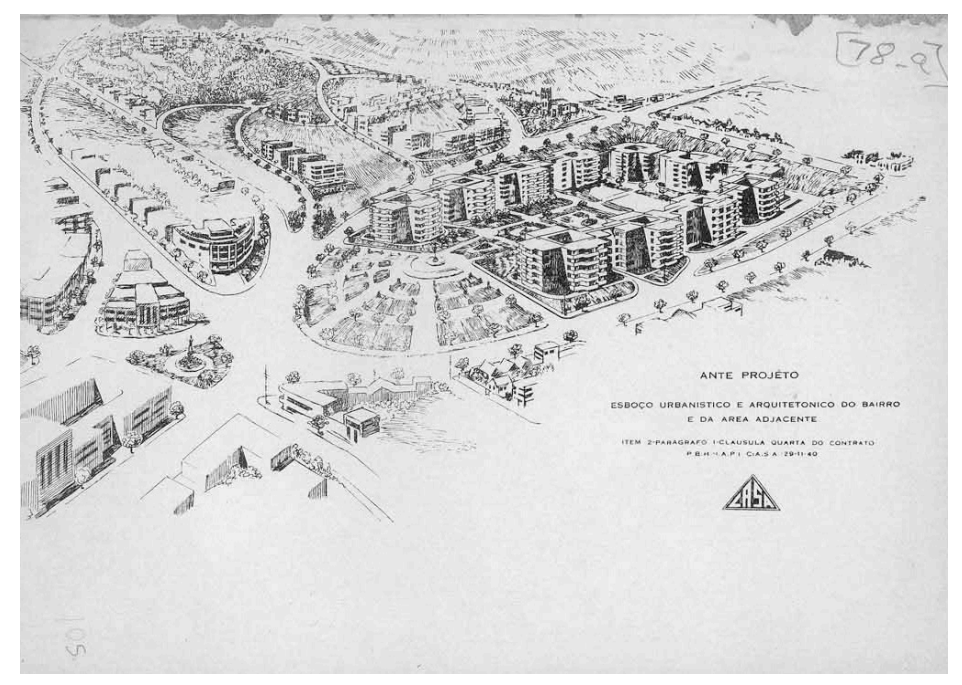

Figure 1. Source: PREFEITURA DE BELO HORIZONTE (1942: 78a). Accessed 23 May 2017. http://www.pbh.gov.br/arquivopublico/relatoriosdosprefeitos/1940-1941-JuscelinoKubitschek-de-Oliveira.pdf. The image shows a planning sketch of the bairro popular (Conjunto IAPI) from the early 1940s. Initially, the PBH and the IAPI had planned to construct eleven buildings, later they reduced the number of buildings to nine.

The construction of the nine vertical buildings lasted from 1944 to 1951. Soon, this housing estate became popularly known as Conjunto IAPI. The analysis of contemporary official documents reveals that Belo Horizonte's municipal authorities presented its proximity to the city center as an important advantage (PREFEITURA DE BELO HORIZONTE 1942: 79). At the same time, the bairro popular project was part of the $\mathrm{PBH}^{\prime} \mathrm{s}$ strategy to destroy illicit settlements, in particular the neighboring favela Pedreira Prado Lopes. ${ }^{11}$ In his annual report of 1940-1941, Kubitschek found the existence of favelas close to the city's central area intolerable (PREFEITURA DE BELO HORIZONTE 1942: 76). Many favelados lost their homes in the context of the Conjunto IAPI's construction. Throughout the following decades, Belo Horizonte's municipal administration established several public institutions in the neighborhood of the social housing complex and kept on tearing down significant parts of the Pedreira Prado Lopes.

\footnotetext{
${ }^{11}$ Since the late $19^{\text {th }}$ century, rural migrants and freed slaves who came to Belo Horizonte moved to the Pedreira Prado Lopes which is one of the city's oldest favelas. Nowadays, about 4.453 inhabitants live in this agglomeration (IBGE, 2011). Over recent decades, violence and drug trafficking have contributed to the infamous reputation of the Pedreira Prado Lopes.
} 
For the residents of the Conjunto IAPI, however, the central location of their place of residence and the implementation of urban infrastructures brought important advantages. In the aforementioned report, Kubitschek had described the foundation of the Bairro Popular (Conjunto IAPI) and Lagoinha's revitalization as an important part of an extensive program of urban reforms which were meant to lead Belo Horizonte to modernization and progress. The construction of the Avenida da Pampulha (nowadays Avenida Antônio Carlos), initiated in 1943, was one of the first large-scale urban development projects in the Lagoinha region. This avenue had far-reaching effects on the living conditions in the Conjunto IAPI in the long run. Above all, it was important for the integration of the public housing estate into Belo Horizonte's public transport network (PETERS, doctoral thesis, defended in 2016, unpublished manuscript). In 1944, a new public hospital, the Hospital Municipal, was opened in front of the Conjunto IAPI. Whereas Kubitschek and the municipal administration emphasized the benefits which the workers would derive from this infrastructure measure (PREFEITURA DE BELO HORIZONTE 1942: 82-86), the establishment of the Hospital Municipal actually had ambivalent impacts on the local social and urban structure: on one hand it offered healthcare to the local population and thus contributed to public welfare. On the other, large parts of the Pedreira Prado Lopes favela were destroyed during the construction works (ARROYO 2010: 103). Some years later, once more many favelados lost their homes when the municipal administration under Américo Renê Giannetti decided to transfer the Colégio Municipal, a public secondary school, to Lagoinha (PREFEITURA DE BELO HORIZONTE 1955: 165). The memories of long-term residents of the Pedreira Prado Lopes indicate that children from the favela never set a foot in this establishment (RIBEIRO et al. 2001: 154-155). For many years, poor school-aged children who lived at the favela also remained excluded from access to education at the Escola Municipal Honorina de Barros, a primary school that was established inside the neighboring Conjunto IAPI in the 1960s (PETERS, doctoral thesis, defended in 2016, unpublished manuscript). At the same time, the foundation of these educational establishments improved the Conjunto residents' quality of life. Many children who lived in the housing complex completed their primary or secondary education at the nearby institutions. Furthermore, adult inhabitants of the Conjunto IAPI found work at the schools. As the interviews with long-term residents reveal, parents participated in the organization of extracurricular activities and made new friendships. ${ }^{12}$ Both educational institutions thus also were important for the consolidation of social ties at the social housing estate. The Colégio Municipal and the Escola Municipal Honorina de Barros are

\footnotetext{
${ }^{12}$ Interview with Roberto (28 August 2013).
}

PRASILIANA- Journal for Brazilian Studies. Vol. 5, n.2 (July, 2017). ISSN 224.5-4373. 
early examples of how the establishment of urban infrastructures in the Conjunto IAPI's neighborhood resulted in processes of socio-spatial segregation. Whereas the poorest parts of the local population were driven out of their homes and excluded from access to public institutions, the inhabitants of the Conjunto IAPI for their part actually benefitted from the proximity to Belo Horizonte's central area, due to the availability of public services in their vicinity and a wider range of job offers in the nearby city center. Several interviewees said that they had worked in the city center once or were still working there. In this context, they emphasized how much the location of the Conjunto IAPI had improved their quality of life since they did not spend a lot of time on commuting. ${ }^{13}$

The residents of many other conjuntos habitacionais in Brazilian cities which were built in the 1940s and the following decades did not have access to comparable infrastructures. As the next section will show, this was largely due to the location of the housing estates in the urban peripheries which have continuously suffered from the shortcomings of urban planning and missing public investment. Having a closer look at the different development that central areas and urban peripheries experienced in the second half of the $20^{\text {th }}$ century also leads to a better understanding of how and why conjuntos habitacionais have acquired the stigma as places where poor people live.

\section{Central Areas and Urban Peripheries of Brazilian Cities}

While there was a permanent lack of coherent and effective public housing politics, a constantly growing number of rural migrants who came to the cities were in need of a place to live. As a consequence, the urbanization of peripheries remained in the hands of private entrepreneurs who offered land plots far away from the central areas. In many cases, these plots were only provided with precarious infrastructure and sold irregularly (CALDEIRA 2000). This was only possible, because the state did not take over responsibility for the provision of housing. Nor did state actors make any serious efforts to inspect the private business. In the central areas, where middle and upper-class groups were living, the favelas grew to previously unknown extent, particularly since the 1950s: a low-income population was occupying public and private areas on hills or streambanks (VALLADARES 2005). In these settlements, many workers lived in self-built houses, due to a lack of economic resources. At the same time, state action in the field of housing remained limited to the construction of large conjuntos habitacionais, high rise- and single-storey housing estates, in

\footnotetext{
${ }^{13}$ Interviews with Roberto (28 August 2013), Tiago (18 September 2012) and Lucas (24 September 2012).
} 
the peripheries of the cities. ${ }^{14}$ In terms of construction quality, these housing estates did not differ much from self-help housing (BONDUKI 2011). Moreover, taking into consideration the average family size, housing units used to be very small, which soon led people to increase the size of their houses (in Brazil this kind of action is known as puxado). The physical appearance of the housing estates and the agglomeration of poor people, many of them removed from favelas in central areas, contributed to the fact that conjuntos habitacionais have acquired a reputation which is as negative and stigmatizing as in the case of favelas (BRUM, 2012, NAZÁRIO; ANDRADE 2012).

Between the 1950s and the 1970s, the urban peripheries grew - in a geographical as well as in a social sense - up to the point that they gave birth to what is known today as the center-periphery model of social segregation; i.e. that the upper- and middle classes are living in central areas where they are provided with infrastructure and services of high quality, while workers are living in the precarious peripheries. In Brazil social scientists and residents use to call the urban peripheries dormitory cities, since these areas have constantly suffered from a lack of services and job offers. The low quality of public transport with buses as predominant means of transportation results in the fact that people spent an enormous amount of time on commuting between their home and place of work (LEIVA 2015).

In the 1970s, popular movements were successful in putting pressure on the state to work towards the improvement of urban living conditions. Nonetheless, the social distances between central areas and peripheries still persist, whether regarding the quality of services, whether regarding one's chances to find a job. (ANDRADE e MENDONÇA, 2010, ANDRADE 2016, RIBEIRO; RIBEIRO 2013). From the 1980s on, the improvement in quality of life in the peripheries - which had been a result of the implementation of some urban infrastructure - was affected in a negative way by the rise in violent crimes, above all murder (ANDRADE; SOUZA; FREIRE 2013).

In Brazil the urban periphery is thus not just a geographical space, but also a social space marked by the presence of people who suffer from a lack of economic resources. The

\footnotetext{
${ }^{14}$ As several authors have argued this was especially the case after the coup d'état in 1964. The military regime was convinced that it was possible to organize social housing with an entrepreneurial approach. As a consequence, workers with better qualifications, high-skilled employees and state functionaries benefitted from state-organized housing whereas the situation for the poor actually got worse. See SILVA 1989, p. 52; MARICATO 2004, pp. 48-51; AZEVEDO; ANDRADE 2011, p. 71.
}

PraSiluanA- Journal for Brazilian Studies. Vol. 5, n.2 (July, 2017). ISSN 2245-4373. 
fact that many conjuntos habitacionais are situated in these areas has contributed much to their reputation as places of the poor.

\section{Conjunto Life and Territorial Stigmatization}

As we have explained above, the research conducted in the Conjunto IAPI on people's experiences of living in the conjunto in the past and present reveals that this housing estate's location within the city has been fundamental in providing access to other rights, including work, education, health, and leisure. Nevertheless, the advantage of its central location is much reduced by its proximity to the Pedreira Prado Lopes favela and by the stigma (in the sense described by Goffman) that housing projects have acquired in Brazil as places where poor people live (stigma of poverty) and other negative attributes associated with that social condition.

One of the most recurrent parallels drawn in the interviews conducted in the Conjunto IAPI was that of the conjunto as a big family. By that the residents meant they all knew each other there, they supported each other, and they formed a cohesive group. The frequency with which this comparison was made suggests that its main aim was to counter the view of the conjunto as a place for poor people either because it is a "housing project" or because it is so close to the Pedreira Prado Lopes favela.

The residents therefore highlighted not only the place's human qualities (a "big family") but also its architectural qualities, which recently were further enhanced

when the conjunto was added to the Cultural Heritage Register and newly painted. ${ }^{15}$ When it was registered, the Conjunto IAPI received highly positive coverage in the media as a cultural asset to the municipality ${ }^{16}$, adding to the already well-established view of it as a big family:

“The IAPI [...] is one family and 928 apartments [...]. We're united here. There's strength in unity. That's a fact that nobody can deny. The fact is

\footnotetext{
${ }^{15}$ The Conselho Deliberativo do Patrimônio Cultural do Município de Belo Horizonte (CDPCM-BH) decided to include the Conjunto IAPI on the list of cultural heritage on 25 April 2007. See PREFEITURA DE BELO HORIZONTE: Diário Oficial do Município Ano XIII Edição N² 2.839 (05/05/2007).

${ }^{16}$ See for instance: HOJE EM DIA (3 October 2006), p. 13: Cara nova para o Complexo do IAPI; ESTADO DE MINAS, 13 April 2011, p. 28: Memória restaurada; ESTADO DE MINAS, 22 June 2011, p. 28: Cores que trazem vida.
}

PRASIlianA- Journal for Brazilian Studies. Vol. 5, n.2 (July, 2017). ISSN 2245-4373. 
there's strength in unity. [...] When people badmouthed this place I would fight back. I couldn't accept that. [...] because here we're next to a shanty town.“ (Leonardo. IAPI resident since 1950. Interviewed on 8 August 2012.)

"And here the fact that we're known [...], we were born here, we're very well known, well respected, if anything happens to us in the street ... it'll protect us. It'll defend us, take our side, that's the IAPI family."(Teresa. IAPI resident since 1957. Interviewed on 8 August 2012.)

“We all know each other here. Everybody knows who your kids are, so it's a family. It's a peaceful place-a small town." (Lucas. IAPI resident since 1981. Interviewed on 24 September 2012.)

This insistence on cohesion through use of the "big family" image derives from the need to counter the negative external image of the Conjunto IAPI. The interviews clearly reveal how much the residents suffer from being confronted with stereotypes held by people who do not know the place. In this context, their statements also show that they feel a strong need to fight such stereotypes by putting forward a positive internal image held by those who really know the conjunto because they live there.

The residents' statements address several aspects of the stigmatization process to which they are subjected. The most recurrent aspect is due to their proximity to the favela. It is as if the historically stigmatized favela environment were contaminating the IAPI and its residents. It is interesting to observe, however-and it was even seen in one of the witness statements - that the stigma of living close to the favela does not affect all areas equally. The prestige associated with some areas makes them immune to the stigma. In these cases the social gap raises a barrier to the idea of "contamination by proximity." In the IAPI's case, the fact that the social gap with the favela is not very great leads to the view that they belong to the same or at least a similar social milieu.

"There used to be, and I think there still is, some discrimination against the Conjunto IAPI. [...] the high-class neighborhoods have favelas close by as well [...], like Buritis, Belvedere and Serra, which all have favelas. They are a little more dangerous than this one here. But as the conjunto is in an ordinary area-it's not located in a high-class place, this conjunto-[people ask,] "Do you live in the favela?" (Lucas. IAPI resident since 1981. Interviewed on 24 September 2012.) 
Another strategy used by the residents to defend themselves from the stigma is to represent the conjunto and the favela as places where only "good people" live, or to try to minimize the differences between the various parts of the city: "Every high-class place and every poor place has its good and bad people." (Lucas. IAPI resident since 1981. Interviewed on 24 September 2012). The residents stated in the interviews that they are on good terms with the favela, since the favela residents respect the IAPI. "They're good folk. We have learned to bring out those good folk's friendship for us. They consider the IAPI their back yard. They all respect it." (Leonardo. IAPI resident since 1950. Interviewed on 8 August 2012.) They also claim that there are no robberies, trafficking or other crimes in the conjunto. Therefore they naturalize violence to show that there is order in the neighboring favela:

"Sometimes a fight here gets shown on TV, but that is only natural, because they get up to mischief, but right up at the top there things get heavy, because they're really tough those guys up there. Because here they can't get up to mischief, they don't accept it here." (Leonardo. IAPI resident since 1950. Interviewed on 8 August 2012.)

The conjunto is also stigmatized for being a large, uniform place (PENZIM, 2001). Furthermore, the residents are convinced that many outsiders see the Conjunto IAPI as a place of poor people, shacks, people who fight or immoral and uneducated people.

Some interviewees also said they had had difficulty getting a job when they gave the IAPI as their address, or that there was distrust of young women, as if they were prostitutes. Teresa compared these reactions to racism: "I think it's like black people facing racism, which they say doesn't exist [...]. It's the same thing. We see what the situation is and get out." (Teresa. IAPI resident since 1957. Interviewed on 8 August 2012.) Another resident complained of people's reluctance to go to the IAPI: "Nobody from outside comes to your home. They're afraid. You have a kid at school and his classmate can't come round because his father won't let him [...]." (Tiago. Interviewed on 18 September 2012.) ${ }^{17}$

The residents highlight aspects such as the size of the apartments and the landscaped areas outside and say that people who do not live there do not know about them.

"Only people who know it here speak well of it. Those who don't know it don't. [...] my apartment is almost 100 square meters in size. It isn't just any

\footnotetext{
${ }^{17}$ These accounts are very similar to the results obtained by Gilberto Velho in his research on a block of one-room apartments in Copacabana neighborhood, Rio de Janeiro (Velho, 1973).
}

PRASILIANA- Journal for Brazilian Studies. Vol. 5, n.2 (July, 2017). ISSN 224.5-4373. 
apartment, like there are today [...]." (Teresa. IAPI resident since 1957. Interviewed on 8 August 2012.)

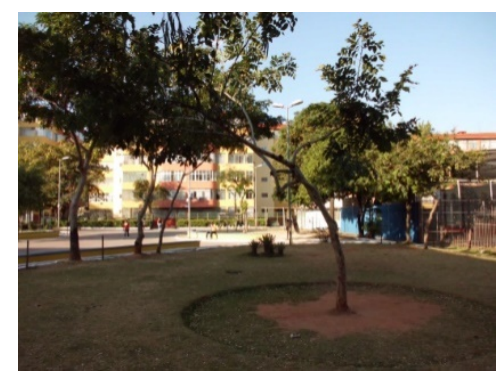

Figure 2

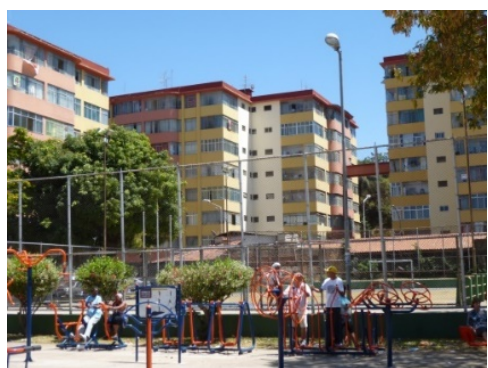

Figure 3

The pictures show the landscaped areas in the Conjunto IAPI. The sports field and leisure areas in the central patio are meeting points for the residents (Photos by Mario Peters, 2012/2014).

The residents report a change in the way the conjunto has been viewed since it was painted and registered:

"And now the conjunto has been painted it has gotten everyone interested, because Coral Paints is international [...]. It made Salvador, it made Rio de Janeiro, it made a number of places. So that made the IAPI better known and people got more curious." (Teresa. IAPI resident since 1957. Interviewed on 8 August 2012.)

"At first we were badly discriminated against, and the painting helped a little, it really helped. It was ugly, it was horrible, everything closed, very dark." (Tiago. Interviewed on 18 September 2012.)

After commenting on the bad reputation the conjunto had gained because of its proximity to the favela, Maria stated:

"But it's the opposite now. "Where do you live?" "In the Conjunto IAPI." Because the revitalization, the cultural heritage registration ..." (Maria. IAPI resident since 1947. Interviewed on 24 August 2012.) 


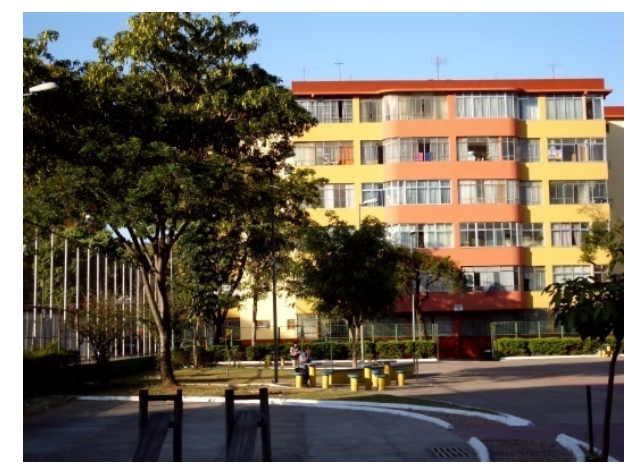

Figure 4

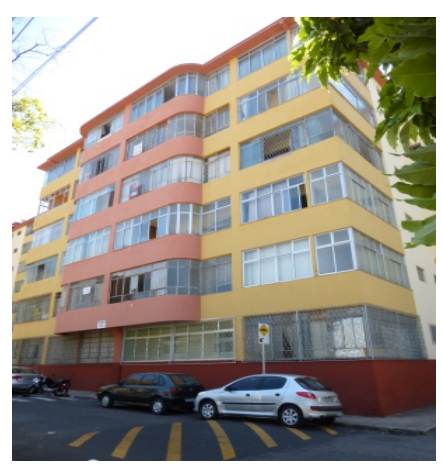

Figure 5

The pictures show the buildings in the Conjunto IAPI after the painting of the facades (Photos by Mario Peters, 2012/2014).

Another aspect that the residents mentioned was the urbanization of the favela, which helped improve living conditions and also affected the aesthetic aspect. It is important to point out that although the conjunto is located very close to the city center and beside a highway linking the center with Pampulha ${ }^{18}$ (which gives it great visibility), it occupies a corner of the Lagoinha district between the highway and the favela, so that nobody is likely to enter the conjunto unless they are going to visit someone there. In addition, the apartment blocks are separated from the street by railings and gardens, so that they stand some distance from the street.

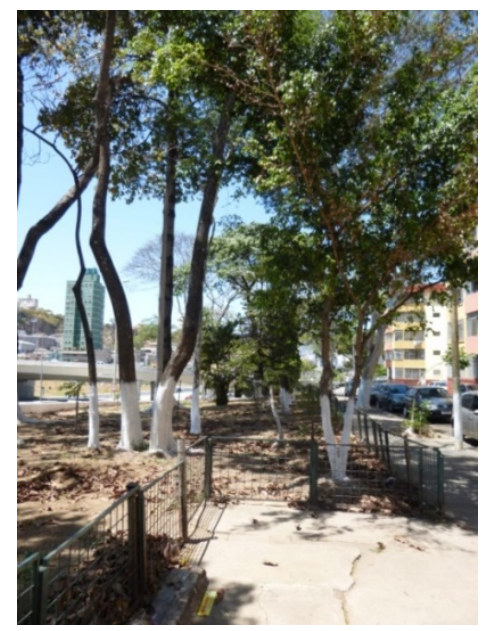

Figure 6. The picture shows the area between the buildings in the Conjunto IAPI and the Avenida Antônio Carlos (Photo by Mario Peters, 2014).

Given the bad reputation that housing projects have acquired in Brazil, with small, substandard buildings, little is known about the qualities of this conjunto in urban planning

\footnotetext{
${ }^{18}$ Pampulha is a high-status residential neighborhood and a tourist attraction because of its lake and the buildings by the modernist architect Oscar Niemeyer.
} 
terms, apart from the generous size of the apartments as revealed by its heritage registration. In the context of its inclusion on the cultural heritage register, a team of local architects produced an analysis of the housing estate's architectonic structure (GEPH/PREFEITURA DE BELO HORIZONTE 2007). A book published recently by Nabil Bonduki and Ana Paula Koury (2014) also includes some considerations about the architecture of the Conjunto IAPI. However, many studies on the history of Brazilian architecture do not discuss public housing estates (BONDUKI 1999). The case of the Conjunto IAPI in Belo Horizonte seems to confirm this general trend since its architectonic peculiarities have largely remained unknown, even among architects.

\section{Conclusion}

Contrary to research on favelas and urban peripheries, the literature on conjuntos habitacionais is scarce. Even less is known about their symbolic representations. In the case of favelas, the negative reputation from which these settlements suffer derives from their historical origin and, to date, urbanization programs have not led to a significant change in this respect (SILVA, 2002). Throughout the last century, the favelas passed through significant transformations, several urbanization programs have been carried out, all of them aimed at urbanizing the favela and integrating it into the city. ${ }^{19}$ Yet favelas remain socially separated from the rest of the city, and also in terms of their urban form. This is also proven by the fact that the IBGE (Instituto Brasileiro de Geografia e Estatística) continues to differentiate between the city and even those favelas that have already been urbanized. All favelas are considered equally as subnormal settlements (assentamentos subnormais). Given their visible presence in central areas, they are seen as enclaves in the "formal city". The change of names from favela to comunidade or vila has not had much effect either. As Silva (2002) put it, the "problem of the favela" continues. As to the conjuntos habitacionais, many of these housing estates were constructed in order to give people who had been removed from favelas ${ }^{20}$ a new place to live. This is one of the main reasons why conjuntos are usually associated with the favela, as poor

\footnotetext{
${ }^{19}$ Favela Bairro in Rio de Janeiro, Vila Viva in Belo Horizonte and Santo André mais igual in Santo André are some wellknown examples.

${ }^{20}$ Alba Zaluar (1985) published one of the most important studies on this topic. In her work, she also discusses the problem of violence that since the $1980 \mathrm{~s}$ has particularly affected favelas and the urban peripheries where most conjuntos habitacionais are situated. See also BRUM (2012). For a study on a conjunto in the Metropolitan region of Belo Horizonte that received removed favela inhabitants and people whose homes had been destroyed by heavy rainfalls see NAZARIO; ANDRADE 2012.
}

ßRASILIANA- Journal for Brazilian Studies. Vol. 5, n.2 (July, 2017). ISSN 224.5-4373. 
people's housing, and with the favelados, the residents of the favelas. While the Conjunto IAPI in Belo Horizonte is an exception in terms of location, it did not escape the stigma, as can be seen in the interviewees' statements.

What the persistence of the stigma shows is that social integration demands more than just the provision of housing. Moreover, the integration into the central area of the city, and a policy against segregation, designed differently from what is actually being done in the context of housing programs for the low-income population will also meet problems of social integration. As our case study shows, the residents of the IAPI were seen in a negative light and labeled as residents of housing estates (moradores de conjunto). In the opinion of most interview participants, the proximity to the favela has made outsiders avoid the IAPI and its residents. Some recent developments, however, indicate that stigma is reversible, or at least, that it can be reduced. The IAPI's registration as cultural heritage of the city, the positive coverage that this act found in the local media, and its positive impact on the residents' selfesteem are important in this respect: for the first time in decades, local newspapers wrote about the Conjunto in positive ways. All the aspects, the residents highlighted in order to free themselves from the stigma, as for example the conjunto's architectural quality, the size of the apartments, the dynamic social life inside the housing estate, were now made known to the public due to the attention that the media gave to the IAPI's registration as cultural heritage by the municipal administration.

These observations show that there are different levels of stigmatization. The stigma of the favela has proven to be much more rooted and a problem difficult to resolve. Moreover, recent developments at the IAPI also indicate that governmental action can contribute to the reduction of stigmas. Furthermore, they reveal the importance of symbolic capital. Favelas, peripheries and conjuntos habitacionais have constantly been portrayed by the media and by social scientists as places marked by social problems (KESSLER, 2012). As Goffman (1975), Bourdieu (1999), Wacquant (2007) and others have already shown, such representations have concrete negative impacts on the residents' opportunities to improve their quality of life. This does not mean that the problem of integration should be reduced to a question of symbolic representation, but we argue here that integration also depends on symbolic representation. In the IAPI's case, the central location, the fact that the residents' living conditions correspond to those of the lower middle class and that they do not suffer from poverty, that they are living in apartments, not in shacks as most people in favelas, open the way for a conversion of this housing estate's symbolic representation. This might have more concrete effects, as for example the valorization of real estate or the integration of the residents. Our study points in 
this direction, however, more research needs to be done before it will be possible to measure the effects of symbolic conversion in relation to such concrete indicators.

\section{Bibliography}

ALMEIDA, Caliane Christie Oliveira de (2007): Habitação Social: Origens e Produção (Natal, 1889-1964) (Dissertação de Mestrado em Arquitetura e Urbanismo). São Carlos: Universidade de São Paulo.

AMORE, Caio Santos, Lucia Zanin SHIMBO e Maria Beatriz Cruz RUFINO (2015): Minha Casa... e a Cidade?: avaliação do programa Minha Casa Minha vida em seis estados brasileiros. Rio de Janeiro: Letra Capital.

ANDRADE, Luciana T. de (2016): O espaço metropolitano no Brasil: nova ordem espacial? In: Caderno CRH vol. 29, no. 76, pp. 101-118.

ANDRADE, Luciana T. de; ARROYO, Michele (2012): Bairros pericentrais de Belo Horizonte. Patrimônio, territórios e modos de vida. Belo Horizonte: Editora PUC Minas.

ANDRADE, Luciana. T. de; D. M. B. de L. SOUZA; F. H.A. FREIRE (Eds.) (2013): Homicídios nas regiões metropolitanas. Rio de Janeiro: Letra Capital.

ANDRADE, Luciana T. de; MENDONCA, Jupira G. (2010): Explorando as consequências da segregação metropolitana em dois contextos socioespaciais. In: Cadernos Metrópole (PUCSP), vol. 23, pp. 169-188.

ARROYO (2010), Michele Abreu: A diversidade cultural na cidade contemporânea: o reconhecimento da Pedreira Prado Lopes como patrimônio cultural (Tese de Doutorado em Ciências Sociais). Belo Horizonte: PUC Minas.

AZEVEDO, Sergio de, ANDRADE, Luis Aureliano Gama de (1982): Habitação e Poder: da Fundação da Casa Popular ao Banco Nacional da Habitação. Rio de Janeiro: Zahar.

AZEVEDO, Sergio de, ANDRADE, Luis Aureliano Gama de (2011): Habitação e Poder: da Fundação da Casa Popular ao Banco Nacional da Habitação , 71. Centro Edelstein de pesquisas sociais, Rio de Janeiro. Accessed 7 May 2015

www.bvce.org/DownloadArquivo.asp?... $<\mathrm{b}>$ AZEVEDO $</ \mathrm{b}>$ _ $<\mathrm{b}>$ ANDRADE $</ \mathrm{b}>$ A $<\mathrm{b}>\mathrm{H}_{\text {Habit }}$ $\mathrm{a}</ \mathrm{b}>$.

BENCHIMOL, Jaime Larry (1992): Pereira Passos: Um Haussmann Tropical: A Renovação Urbana da Cidade de Rio de Janeiro no Início do Século XX. Rio de Janeiro: Prefeitura. 
BONDUKI, Nabil (2011): Origens da Habitação Social no Brasil: arquitetura moderna, lei do inquilinato e difusão da casa própria.5th Ed. São Paulo: Estação Liberdade; FAPESP (first published in 1998).

BONDUKI, Nabil (1999): Habitação no Brasil: uma história em construção. In: Anais Encontros Nacionais da ANPUR 8. Porto Alegre 1999, 14 pages. Accessed 10 May 2015 http://unuhospedagem.com.br/revista/rbeur/index.php/anais/article/viewFile/1956/1918.

BONDUKI, Nabil; Ana Paula KOURY (Eds.) (2014): Pioneiros da habitação social. 3 Volumes. São Paulo: Editora UNESP, Edições SESC.

BORDIEU, Pierre (1999): Efeitos do lugar. In: Pierre Bourdieu (Ed.): A miséria do mundo. Petrópolis: Editora Vozes, pp. 159-166.

BOTAS, Nilce Cristina Aravecchia (2011): Entre o progresso técnico e a ordem política: arquitetura e urbanismo na ação habitacional do IAPI (Tese de Doutorado em Arquitetura e Urbanismo). São Paulo: USP.

BRUM, Mario Sergio (2012): Ditadura civil-militar e favelas: estigma e restrições ao debate sobre a cidade (1969-1973). In: Cadernos Metrópole. Vol. 14 no. 28, pp. 357-379.

BRUNA, Paulo Júlio Valentino (2010): Os primeiros arquitetos modernos: habitação social no Brasil 1930-1950. São Paulo: EDUSP.

CALDEIRA, T. P.do R. (2000): Cidade de muros: crime, segregação e cidadania em São Paulo. São Paulo: Editora 34/EDUSP.

CARDOSO, Adauto L. (Ed.) (2013): O Programa Minha Casa Minha Vida e seus Efeitos Territoriais. Vol.1. Rio de Janeiro: Letra Capital.

FERRARI, Camila (2013): Projetos de Habitação Popular como projetos de cidade moderna: os conjuntos habitacionais dos IAPs na Grande São Paulo de 1930 a 1964. (Dissertação de Mestrado em Arquitetura e Urbanismo). São Carlos: Universidade de São Paulo.

GEPH/PREFEITUA DE BELO HORIZONTE (2007): Dossiê de Tombamento Conjunto Residencial São Cristovão-IAPI. Belo Horizonte: Prefeitura.

GOFFMAN, Erving (1975): Estigma: notas sobre a manipulação da identidade deteriorada. Rio de Janeiro: Zahar.

IBGE. Instituto Brasileiro de Geografia e Estatística (2011): Censo Demográfico de 2010. Rio de Janeiro.

KESSLER, Gabriel (2012): Las consecuencias de la estigmatización territorial: Reflexiones a partir de un caso particular. In: Espac. blanco, Ser. indagaciones vol. 22, no.1, pp. 165-197.

ßRaSILIANA- Journal for Brazilian Studies. Vol. 5, n.2 (July, 2017). ISSN 2245-4373. 
Accessed 5 March 2017. <http://www.scielo.org.ar/scielo.php?script=sci_arttext\&pid=S151594852012000100007\&lng=es\&nrm=iso>. ISSN 1515-9485.

LEIVA, Guilherme de C. (2015): Viagens intrametropolitanas casa-trabalho na RMBH. In: Luciana Teixeira de Andrade, Jupira Gomes de Mendonça, Alexandre Magno Alves Diniz (Eds.): Belo Horizonte: transformações na ordem urbana. Belo Horizonte, Rio de Janeiro: Editora PUC Minas/ Letra Capital Editora LTDA.

MARICATO, Ermínia (2004): Habitação e Cidade. 7th Ed. São Paulo: Atual.

MELO, Marcus André B.C. de Melo (1991): Estado e Mercado: A Construção Social da Agenda do Estado na Esfera da Habitação, 1930-1990. In: Anais Encontros Nacionais da ANPUR 4, pp. 103-111. Accessed 6015. http://unuhospedagem.com.br/revista/rbeur/index.php/anais/article/view/1752/1720

NAZÁRIO, Rejane de O., ANDRADE, Luciana T. de (2012): "Da favela para o conjunto": A periferia no entorno da cidade administrativa de Minas Gerais. In: Cadernos de Arquitetura e Urbanismo, vol. 17 no. 21, pp. 54-71.

PENZIM, Adriana M. B. (2001): Viver em Conjunto: Habitação Social e Modos de Vida. (Dissertação de Mestrado em Ciências Sociais). Belo Horizonte: Pontifícia Universidade Católica de Minas Gerais.

PETERS, Mario: Social Housing, Socio-Spatial Segregation and Territorial Stigmatization in Brazil: The Conjunto IAPI, Belo Horizonte, circa 1940-1973. Doctoral Thesis. Defended in 2016. Unpublished Manuscript.

PREFEITURA DE BELO HORIZONTE (2007): Diário Oficial do Município Ano XIII Edição Nº $2.839(05 / 05 / 2007)$.

RIBEIRO, Núbia Braga et al. (Ed.) (2001): Becos da memória, desenhos da cidadania: Pedreira Prado Lopes: a vila no trajeto de sua história oral. Belo Horizonte: UNI-BH.

RIBEIRO, Luíz C.Q.; RIBEIRO, Marcelo G. (Eds.) (2013): IBEU: Índice de Bem-estar Urbano. Rio de Janeiro: Letra Capital.

SANTOS, Wanderley Guilherme dos (1979): Cidadania e justiça: a política social na ordem brasileira (= Contribuições em Ciências Sociais 1). Rio de Janeiro: Campus.

SILVA, Luiz Antonio Machado da (2002): A continuidade do "problema da favela". In: Lúcia Lippi Oliveira (Ed.): Cidade: história e desafios. Rio de Janeiro: FGV, pp. 220-237.

SILVA, Maria Ozanira da Silva e (1989): Política Habitacional Brasileira: verso e reverso. São Paulo: Cortez.

ßraSILIANA- Journal for Brazilian Studies. Vol. 5, n.2 (July, 2017). ISSN 2245-4373. 
VALLADARES, Lícia do Prado (2005): A invenção da favela: do mito de origem à favela. com. Rio de Janeiro: FGV.

VELHO, Gilberto (1973): A Utopia Urbana: um estudo de antropologia social. Rio de Janeiro: Zahar.

WACQUANT, Loic (2007): Territorial stigmatization in the age of advanced marginality. In: Thesis Eleven no. 91(1), pp. 66-77.

ZALUAR, Alba (1985): A máquina e a revolta: as organizações populares e o significado da pobreza. São Paulo: Brasiliense.

\section{Primary Sources}

ESTADO DE MINAS (13 April 2011), p. 28: Memória restaurada.

ESTADO DE MINAS (22 June 2011), p. 28: Cores que trazem vida.

HOJE EM DIA (3 October 2006), p. 13: Cara nova para o Complexo do IAPI.

PREFEITURA DE BELO HORIZONTE (1942): Relatório do prefeito Juscelino Kubitschek Oliveira para o Governador Benedicto Valladares Ribeiro. Belo Horizonte: Prefeitura. Accessed 23 May 2017. http://www.pbh.gov.br/arquivopublico/relatoriosdosprefeitos/1940-1941-JuscelinoKubitschek-de-Oliveira.pdf

PREFEITURA DE BELO HORIZONTE (1955): Prestação de Contas do Executivo Municipal relativa ao exercísio de 1954 encaminhada à Egrégia Câmara dos Vereadores em Fevereiro de 1955. Belo Horizonte: Prefeitura. Accessed 25 October 2015. http://www.pbh.gov.br/arquivopublico/relatoriosdosprefeitos/1954-I-Sebastiao-de-Brito.pdf

\section{Interviews}

Interview with Maria (24 August 2012).

Interview with Tiago (18 September 2012).

Interview with Leonardo and Teresa (8 August 2012).

Interview with Lucas (24 September 2012).

Interview with Teresa (18 September 2012).

Interview with Gilberto, Teresa and Cristiano (19 February 2013).

Interview with Roberto (28 August 2013). 